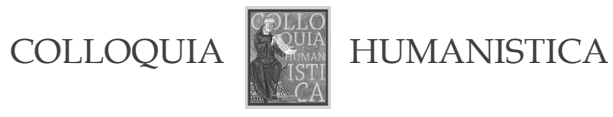

\title{
Irina Koluzaeva
}

Faculty of "Artes Liberales"

University of Warsaw, Warsaw

acoro@rambler.ru

\section{"Within One's Inner Circle": The Identity of Ruthenian Szlachta (Noblemen) of the Grand Duchy of Lithuania at the Time of the Union of Lublin (the Case of Filon Kmita Czarnobylski)}

\begin{abstract}
Ianushkevich The main aim of this article is to reconstruct the Ruthenian nobleman's (szlachcic) perception of "us" and "the sphere of familiarity" in the second half of the sixteenth century and to place him within his respective communities and social groups by analyzing successive levels of his identity.

It seems to be particularly important to study ideas and awareness of the common representative of the Ruthenian political nation of the Grand Duchy of Lithuania, as scholars have so far been paying attention only to the notions of identity held by particular representatives of the elite, or else by intellectuals. Clientelist relationships of particular Ruthenian families, which are of crucial importance for reconstructing the complete image of the period, have not commonly been the subject of scientific research.

The main thesis posited by this work is that the perception of one's inner, familiar circle, of "us" as opposed to "them," in the case of Ruthenian nobility was as multilevel as their national identity.

To elucidate the posed questions, I am going to analyze Filon Kmita's personal correspondence, his public, family and matrimonial relationships, the social practices he engaged in, and military and official environments to which he belonged.
\end{abstract}

This is an Open Access article distributed under the terms of the Creative Commons Attribution 3.0 PL License (creativecommons.org/licenses/by/3.0/pl/), which permits redistribution, commercial and non-commercial, provided that the article is properly cited. (C) The Author(s), 2016

Publisher: Institute of Slavic Studies, Polish Academy of Sciences

Editor-in-chief: Jolanta Sujecka

Conception and academic editing of this issue: Jolanta Sujecka 
Such approach can help us not only to reconstruct the circle of relationships of this remarkable person but also to show how one of three primary nations of the Polish-Lithuanian Commonwealth - the Ruthenians - was experienced from the perspective of one of its representatives.

Keywords: Grand Duchy of Lithuania, nobility, identity, Rus', Ruthenia, sixteenth century

Thile talking about identity in its historical dimension, there is always a temptation of imposing present-day, supposedly common forms of identity to the people from even remote past. Equipped with the knowledge about the contemporary nations, we apply these categories to the past, instead of seeking to recreate who the people we study felt to be. In this paper, I am going to analyze the problem of identity in the PolishLithuanian Commonwealth at the time of the Union of Lublin (1569) from the point of view of its citizen - Filon Kmita Czarnobylski, the starosta ${ }^{1}$ of Orsha and the Palatine (Voivode) of Smolensk. ${ }^{2}$

The personality and the epistolary heritage of the starosta of Orsha have attracted the attention of researchers since the first publication of his letters to the senators of the Grand Duchy of Lithuania in 1844 (Malinowski, 1844). This correspondence took place during the first interregnum and the short reign of Henri de Valois. The first edition of letters was also supplemented by the first academic biography of Filon Kmita (Malinowski, 1844, pp. 306-344). His correspondence was considered by scholars not only from the perspective of political history of the Grand Duchy of Lithuania but also as a source for studies on the old Ruthenian culture and language (Karskil̆, 1916, p. 111; Hrushevs'ky1, 1995, p. 223; Korshunaŭ, 1975; Saverchanka, 2006; Rusetskiĭ \& Rusetskiŭ, 2008, pp. 223-224). Kmita's references to Ruthenian epic stories also drew attention from scholars (Veselovskiü, 1881, pp. 61-64; Sobolevskiŭ, 1889; Miller, 2015, pp. 558-564).

In previous studies, the identity of Filon Kmita was considered "Lithuanian" in one way or another (Litwin, 2011, p. 4). Marzena Liedke additionally noticed the high degree of his loyalty towards the monarch (Liedke, 2004b, p. 195).

In my present research I would like to revisit this question using the anthropological approach which was successfully applied in studies by Maria

\footnotetext{
1 In the sixteenth century, the starosta grodowy (hradskiy starosta) was an official supervising on behalf of the Grand Duke of Lithuania (or the King of Poland) the administration and judiciary in a land, most typically a powiat (povyet).

2 Throughout Filon Kmita's life, Smolensk belonged to the Grand Duchy of Moscow and then to the Tsardom of Russia, the office was thus merely titular.
} 
Koczerska and Sławomir Gawlas on Jan Długosz's identity (Koczerska, 1970; Gawlas, 1983) or Natalia Iakovenko's investigation of the components of the "life-space" of Ioakim Yerlich (Iakovenko, 2012).

In order to achieve the objective of defining Kmita's subsequent identity levels, or layers, including his national identity, I am going to place him in his "we-groups" by showing in as much detail as is possible his family and official ties and demonstrating his own perception of these inner circles. Such an approach can help us better understand the features that determined the particular we-groups and the criteria of selfhood (Nowicka, 1990) current within each of them.

In the first part of this paper I am going to study Kmita's family and official ties and outline the character of these relationships. The second part will be devoted to Kmita's possible understanding of his "inner-circle."

Filon Kmita was born in 1530 (Eberle, 1967-1968). In 1564, the Hospodar (Grand Duke of Lithuania) Sigismundus Augustus granted to him, with the right of inheritance, the estate of Czarnobyl (present-day Ukrainian city of Chornobyl'). Thereafter Kmita assumed the agnomen Czarnobylski (Akty, otnosiashchiiesia $k$ istorii Zapadnoi Rossii, sobrannye $i$ izdannye arkheograficheskoiu komissieiu, 1848, p. 249). In 1566, he became a starosta of Orsha, and in 1579 he was appointed as the Palatine of Smolensk. Filon Kmita died in 1587, having remained faithful to the Orthodox Church all his life (Lulewicz, 1977, p. 430)

The origin of the house of Kmita could seem obvious from a huge number of accounts in armorials. Natalia Iakovenko's research on genealogy of the Ukrainian part of Ruthenian nobility considers the families of Kmita, Olizar and Hornostaj to derive from a common Bratslavian progenitor (Iakovenko, 2008, p. 168). Nevertheless, this fact, while accepted by historians (Litwin, 2009 , p. 42), remains difficult to prove based on sources. The Kmitas are always presented as strongly rooted in the land of Bratslav (since 1566, the Palatinate of Bratslav). We know that ancestors of Filon Kmita (the Aleksandrovich family) had held their offices and estates in this land from the fifteenth century. The first mention of person most possibly related to the Kmitas dates back to the first half of the fifteenth century (according to different versions - 1431 or 1446) (Iakovenko, 2008, pp. 169, 400). Kmita (Kmyta) appears as tenant of the lands stretching from the river Zgar to Lityn in the Powiat of Bratslav; later on, the Kmityczs are often seen as a starostas of Vinnytsia, Cherkasy, Zhytomyr, Putyvl. Filon's father, Semen, alongside his brother (Filon's uncle), Krzysztof (Krishtof, Hrystofor), often engaged in the Grand Duke's military endeavors.

More problematic is the question of Semen Kmita's wife, and mother to Filon Kmita. Natalia Iakovenko states that he was the son of Duchna 
(Agrafena) Łukomska (Iakovenko, 2008, p. 179) This is doubtful, as Duchna's first husband, Michał Osowicki, died in 1550 (Wolff, 1895, p. 218), and by that time Filon Kmita had doubtlessly already been born.

It is much more believable that his mother was one of previous two wives of Semen Kmita - Owdotia (Ovdotia) Kapusta or Tatianna (Tatiana) Kroszyńska. This latter family originated from the central part of the Grand Duchy of Lithuania - the Powiat of Nowogródek (Navahrudak) (Temushev, 2007, p. 307) - and in the fifteenth century obtained land tenures in the east of the Vyazma Land. When Vyazma was captured by Moscow, the Kroszyńskis lost their estates and moved to Smolensk, which they also eventually finally left in 1514 (Pietkiewicz, 1995, pp. 143-145). Approximately at that time, the Kroszyńskis intermarried with the Sapieha family, which originated from the Smolensk Land and had held high offices at the court of the Grand Duke of Lithuania since the reign of Alexander Jagiellon and his wife Helena (Pietkiewicz, 1995, pp. 24-25, 143). The Kapusta family, in its turn, held the title of Prince (Kniaz') and had its origins in the Kiev Land (Wolff, 1895, pp. 157-159).

Filon Kmita had two wives - Nastasja Hornostaj and Zofia Chodkiewicz (Khodkevich). Nastasja Hornostaj was a daughter of Iwan (Ivan) Hornostaj, the Palatine of Nowogródek (Eberle, 1967-1968, pp. 88-89). The marriage was short-lived: her first husband - Hrehory Sanguszko Kowelski (Sangushko of Kovel) - died in 1555, and in $1563 \mathrm{Kmita}$ was already married to Zofia Chodkiewicz, as attested to by a document published by Malinowski and Przeździecki (1844, p. 314). Through his second marriage, Filon Kmita entered, alongside Prince Roman Sanguszko and Paweł Sapieha, the so-called "circle of Hrehory Chodkiewicz's sons-in-law." This alliance was strengthened by official interactions. Kmita's appointment to the position of the starosta of Orsha was subject of interest of Hrehory Chodkiewicz, who sought to control all strategically important fortified points in the country (IAnushkevich, 2007, pp. 181, 283). From the 1560s on, we have plentiful evidence of their collaboration, which testifies to the fact that Kmita enjoyed great confidence from the Grand Hetman. Chodkiewicz helped Kmita in financing his rota (hired military unit) (Arkheograficheskī sbornik dokumentov, otnosiashchikhsia $k$ istorïi Severo-Zapadnol Rusi, 1867b, p. 237); Kmita, in his turn, in order to have resources to pay his soldiers, put his estate Pikov (Pykiv) at the disposal of the Grand Hetman (Krykun, 2008, p. 185). When Roman Sanguszko had to temporarily leave his office of Field Hetman due to other official duties, his father-in-law Hrehory Chodkiewicz asked the Grand Duke to allow Kmita to substitute Sanguszko (Archiwum Książąt Sanguszków w Stawucie, 1554-1572, 1910, pp. 198, 200). This shows that the starosta 
of Orsha belonged to the circle of Grand Hetman's confidants, reliable enough to entrust him with command of the Field Hetman's troops. A document listing the administrative and military expenses paid for by Kmita with his own funds during the period of 1567-1570 gives us some idea of the extensiveness of his dealing with the Officials of the Grand Duchy of Lithuania - predominantly the both hetmans (Arkheograficheskĭ sbornik dokumentov, otnosiashchikhsia $k$ istorīi Severo-Zapadnol Rusi, 1867b, p. 248).

The main part of Kmita's service coincided with the time of the Livonian War, fought predominantly with armies of mercenaries. These were based on a system of rotas, or companies. The system had a rotmistrz (rota commander) raise a certain number of "companions" under conditions described in so-called "letters of inscription" (listy przypowiednie), issued by the Grand Duke. Each companion was personally known to the rota commanders, or recommended to them by one of the already enlisted companions (Augustyniak, 2004, p. 21). The soldiers were supposed to be paid from the Treasury but in a war situation often there were problems with financing the hired army, so the magnates who were rota commanders paid soldiers from their own monies. A register of Kmita's cavalry rota survives from 1567 (Arkheograficheskĭ sbornik dokumentov, otnosiashchikhsia $k$ istorii Severo-Zapadnoĭ Rusi, 1867b, pp. 214-224), from which we know that Kmita also hired Cossacks, both from the Ruthenian part of the Grand Duchy of Lithuania and from the Zaporozhian Host, as well as Tartars.

During his military service as a rotmistrz, Filon Kmita cooperated with other rota commanders. In 1562, side by side with Kalenicki Tyszkiewicz (Tyshvkevich) (the starosta of Homel) he beat the Muscovite army near Starodub (Arkheograficheskī sbornik dokumentov, otnosiashchikhsia $k$ istorïi Severo-Zapadnŏ Rusi, 1867b, p. 7; Ianushkevich, 2007, p. 57). Later, in 1564 also with Kalenicki Tyszkiewicz as well as the starosta of Braslav Ościk (Ostsik) and the starosta of Ovruch Andrej Kapusta he took part in the Battle of Ula. After the council in Traby in 1565, where Sigismundus Augustus requested that the magnates supply more troops, Kmita was the first to declare the recruitment of a military unit from his personal funds (Arkheograficheskĭ sbornik dokumentov, otnosiashchikhsia $k$ istorï Severo-Zapadnŏ Rusi, 1867b, p. 212; Ianushkevich, 2007, p. 173), with other rota commanders: Hrehory and Jan Chodkiewicz, Konstanty Wiśniowiecki (Vishnevetskiy), Mikołaj Dorohostajski, Malcher Snowski (Malher Snovski), Hrehory Wojna, Juryj Ościk, Mikołaj and Paweł Sapieha, Michał Koziński, Paweł Pac (Pats), Jan Szymkowicz (Shymkovich), Ostafi Wołłowicz (Volovich), Andrej Kurbski and Stanisław Dziewiałtowski (IAnushkevich, 2007, p. 174). 
During the main campaigns of Stephen Batory's reign, Filon Kmita mainly captained the regiments on his own (as in the operation under Smolensk in 1580) under orders of two hetmans - Mikołaj Rudy ("The Red") Radziwiłł and Krzysztof Piorun ("The Thunderbolt") Radziwiłł on the side theater of operations. His most famous expedition was undertaken during the siege of Pskov by the regiment led by Kmita along with Krzysztof "The Thunderbolt" Radziwiłł, Mikołaj "The Red" Radziwiłł and Michał Haraburda (Kotarski, 1972, p. 19).

Nevertheless, personal relations between Kmita and Krzysztof Radziwiłł were not very good, as is testified to by their land disputes of 1585 (Batory, 1585).

A figure with whom Kmita was in constant interaction was Prince Konstanty Ostrogski (Ostrozhskij), the Palatine of Kiev. They continuously collaborated during the Livonian War: in 1562 Ostrogski ordered Kmita and the starosta of Homel Kalenicki Tyszkiewicz to launch an expedition against Moscow, in which they were victorious (Arkheograficheskĭ sbornik dokumentov, otnosiashchikhsia $k$ istorii Severo-Zapadnoŭ Rusi, 1867b, p. 7); later, in 1565 Ostrogski and Kmita failed their common expedition to the Chernihov Land (Arkheograficheskĭ sbornik dokumentov, otnosiashchikhsia $k$ istorii Severo-Zapadnoĭ Rusi, 1867b, p. 210). However, while the Palatine of Kiev entrusted Kmita with leading his men, letters of Ostrogski to Kmita seem to be letters of a patron to his servant, despite addressing Kmita as a "friend" and "ally" (Arkheograficheskĭ sbornik dokumentov, otnosiashchikhsia $k$ istorii Severo-Zapadno ̌ Rusi, 1867a, pp. 153-154). Communicating his instructions (which in practice were orders), Konstanty Ostrogski warned against inexact execution, which could result in exclusion from his circle of allies (Arkheograficheskĭ sbornik dokumentov, otnosiashchikhsia $k$ istorï Severo-Zapadnol̆ Rusi, 1867a, p. 154).

In connection with the military service, one more issue is worth mentioning. When asked by Kmita to support his military actions against Moscow, the starosta of Homel Kalenicki Tyszkiewicz answered that he was ready to depart with his rota, "яко звыкли предкове наши служити върне а правдиве господарю своему, такъ тежъ и я естемъ ку тому охотливый и буду у вашей милости" (Arkheograficheskĭ sbornik dokumentov, otnosiashchikhsia $k$ istorïi Severo-Zapadnol Rusi, 1867a, p. 155). This quote shows that it was not only family memory which preserved and transferred remembrances of military service under the Grand Duke's orders, but also collective memory shared among noblemen, probably going back to service in royal troops, the so-called "court banners" (choragiew nadworna

\footnotetext{
"As our ancestors used to serve faithfully and honestly their Hospodar, so am I eager for it and I shall accompany your Grace" (all translations in footnotes are mine - I.K.).
} 
I nadvorna kharuhva) of Alexander Jagiellon and Sigismundus I the Old (Lesmaitis, 2013, pp. 44-49, 108).

Ostafi Wołłowicz seems to be one of Filon's Kmita closest allies. Wołłowicz repeatedly hosted Kmita in his houses in Vilnius and Grodno (Korshunaŭ, 1975, p. 69; Krykun, 2008, p. 415). Sources do not provide us with detailed accounts of their interaction - focusing mainly on its official aspect: Ostafi Wołłowicz held the post of the Grand Treasurer of Lithuania (Podskarbi Wielki Litewski) since 1561 (Lulewicz \& Rachuba, 1994, p. 157) and was responsible for paying salary to the soldiers of hired units. The fact of their acquaintance and close contacts is reflected only in Kmita's letters to Wołłowicz. The issue of their correspondence will be expanded in the second part of this paper, but here it is worth mentioning that in contrast to the rest of Kmita's letters, those to Ostafi Wołłowicz and his wife Teodora Wołłowicz (née Sapieha) stand out for their affective overtones. Wołłowicz converted to the reformation ideas in the 1550s and until his last days remained a member of the Calvinist Church (Liedke, 2004a, p. 115).

It seems that another important ally of the Kmitas was the family of Sapieha. Apart from possible contacts from the beginning of the sixteenth century, both Kmita and Paweł Sapieha were sons-in-law of the Grand Hetman Hrehory Chodkiewicz. Representatives of Sapieha had land properties in the Powiat of Orsha and held offices there. Iwan Sapieha was the vice-starosta of Orsha during Kmita's tenure (Czwołek, 2012, p. 23). His son, Lew (Lev) - the future Chancellor and Grand Hetman of Lithuania came back to the Commonwealth of Poland and Lithuania (Rzeczpospolita) after studying in Leipzig, worked as a scribe in Orsha Chancellery, and went on to take the office of vice-starosta in 1577 (Czwołek, 2012, p. 23; Lulewicz, 1994, p. 84). At that time Filon Kmita even offered his protection to young Lew Sapieha after the latter invaded an estate of Hawryło Horonostaj. From a letter of Stephen Batory we know that not only did Kmita make no attempts to settle the dispute in which his vice-officer was involved but, what is more, the invasion probably took place on Kmita's orders (Batory, 1577; Slizh, 2009, pp. 117-118). During the times of his study in Leipzig, Lew Sapieha converted to Calvinism and consequently sympathized with Arianism but in 1586, under the influence of Piotr Skarga, he accepted Catholicism. His religious affiliation did not hinder Filon Kmita from assigning him as a guardian of his children in his bequeathal (Czwołek, 2012, p. 47).

The descendants of the Palatine of Smolensk were also associated with the Sapieha family. Filon's daughter, Zofia married Lew Sapieha's cousin Łukasz Sapieha (Eberle, 1967-1968, p. 89). And, as mentioned, Filon himself 
in the last will ${ }^{4}$ left his son Łazarz in the care of Bohdan and Lew Sapieha (Prochaska, 1892, pp. 7, 55).

Filon Kmita's another son-in-law was Jurij Abramovich Drucki-Horski - the husband of Bohdana Kmita, who served in the Powiat of Orsha under Filon's command (Wolff, 1895, p. 140). After the death of the latter, Drucki-Horski entered the circle of allies of Konstanty Ostrogski, the Palatine of Kiev, and energetically supported his opposition to the 1596 Union of Brest.

In the Palatinate of Kiev, the Kmita family was related also to the family of Proskura-Suszczański - Filon's sister, Owdotia (Niewidanna) Semenówna married Iwan Proskura-Suszczański (Źródła dziejowe, 1894, p. 33; Litwin, 2009, pp. 47, 146).

Lacking a list of all Kmita's estates, we have very poor knowledge of his servants but evidence from his land disputes does provide us with some information in this regard. In connection with a conflict with Gniewosz Stryżowski we know several names of the Pykov estate administration Matwiej Uglik, Aleksandro Bubnovich (Krykun, 2008, pp. 357-358), Jakub Powsza (Povsha). Matwiej Uglik and Jakub Powsza ran several raids on Stryżowski's posessions (it is not certain whether those raids took place on Filon Kmita's orders, but probably so). The Powsza family had long been related to the house of Kmita: Filon's aunt Liudmila was wife of Michał Powsza (Lietuvos Metrika, 2001, p. 295; Boniecki, 1907, p. 188; Litwin, 2009, p. 60), the Powsza may thus be listed as servants-relatives.

Jakub Powsza and above-mentioned Iwan Proskura-Suszczański owed their participation in General Diets as Kiev representatives to relations with the family of Kmita (Litwin, 2009, pp. 47, 60).

During the General Diet of 1581, Kmita's representatives - Wawrzyniec Dudkowicz and the servants Jakub Powsza and Fedor Iasymowich deputized him regarding conflict with Gniewosz Stryżowski (Krykun, 2008, p. 291). Later, on 15 March 1581 Kmita was deputized in this case by Mikołaj Jasieński - the Hospodar's scribe and Chamberlain (Podkomorzy) of Vilnius - and Dymitr Chalecki - the Sword Bearer (Miecznik) to the Grand Duke of Lithuania, who became an ally of the family of Sapieha during the reign of Stephen Batory, and converted to Catholicism at the end of the 1580s (Krykun, 2008, p. 296; Halecki, 1937, pp. 247-248).

When moving to the second part of my study, in which I will ponder the possible understanding of Filon Kmita's inner circle on the part of Kmita himself, it is worth to notice that due to its situational nature, his correspondence is a source which can hardly help us adequately describe

\footnotetext{
The last will of Filon Kmita itself has not survived but this can be ascertained on the basis of other sources.
} 
the local identity of Filon Kmita, his "small homeland." Nevertheless, it sheds some light on his feeling of belonging to the subsequent circles and the character of his relations with every addressee.

As it was already mentioned, in previous studies Filon Kmita was mainly treated as a Lithuanian. In view of this, I would like to start with his own possible understanding of this term.

For Kmita, the word "Lithuania" predominantly means "the Grand Duchy of Lithuania." These terms can be treated as interchangeable and determining "our state." Kmita referred to the Grand Duchy of Lithuania as "Панство его королевской милости" (Korshunaŭ, 1975, p. 54), or just "Litva" (Lithuania), as when he wrote that Ivan Vasylyevich (the Terrible), the Grand Duke of Moscow "выличает вси збродни, чим его отсель 3 Литвы зводили часу нещастного, без государя будучи.”6 (Korshunaŭ, 1975, p. 67). Kmita's Lithuania is a territory limited by official boundaries (Korshunaŭ, 1975, pp. 54, 63, 84, 96, 98). In other words, Lithuania is a state comprising the lands over which the Grand Duke, or Hospodar, has his jurisdiction. However, due to the fact that the majority of his known letters come from the period of the long interregnum after the death of Sigismundus Augustus, Kmita usually took orders from the administration of the state - “вряд панства" (Korshunaŭ, 1975, p. 69).

In his letters to Mikołaj „the Red” Radziwiłł (the Palatine of Vilnius and the Chancellor in 1566-1579) one can clearly sense mistrust towards the Crown administration. Kmita asks if he should allow crossing the border to those who return from Moscow with safe conducts passes sealed with the Crown seal only and lacking the seal of the Grand Duchy of Lithuania (Korshunaŭ, 1975, p. 69). Such a question was probably caused not by Kmita's Lithuanian separatism but by his awareness of Mikołaj Radziwiłł's and his surrounding senators' negative attitude towards the Union of Lublin.

In his letter to Ostafi Wołłowicz from 1 June 1574, Kmita uses the term "Lithuania" (Litva) when describing the subject of the Council in Rudniki - he was ordered to write to the Grand Duke of Moscow, "especially since it was about Lithuania” - "звлаща иж о Литву шло” (Korshunaŭ, 1975, p. 70). Kmita emphasises that all the actions he undertook were for the sake of the Grand Duchy of Lithuania (Floria, 1975, pp. 65-66): he did not seek breakup of the personal union between the Polish Crown and the Grand Duchy of Lithuania but rather "писал, хотячи сына его [the Grand Duke of Moscow - I.K.] государем мети и панов рад корунных на то вести.””

\footnotetext{
5 "The state of His Royal Grace."

6 "[...] lists all the ways he was deceived from here, from Lithuania during the miserable time without sovereign."

7 "I wrote wanting to have his son as the Duke and to lead to it the lords of the Crown."
} 
In two of Kmita's known letters: to Ostafi Wołłowicz of 5 August 1574 (Korshunaŭ, 1975, pp. 85-90) and to Roman Sanguszko of 1 September 1567 (Archiwum Książąt Sanguszków w Sławucie, 1554-1572, 1910, pp. 187-188) we encounter the usage of the term "Lithuania" side by side with "Rus" in the sense of what in present-day terms could be described as an ethnic group.

On the basis of these two letters, we can attempt to specify the interrelations of the terms "Lithuania" and "Rus" in Kmita's understanding. When celebrating Roman Sanguszko's victory over the Muscovite army, Kmita likens this triumph to the victory of the fabled prince Roman over Lithuanians ("Lithuania" - Litva): “Будь господарю таким Романом, што Литвою шрал, шва за помочю Божею то отменишъ, што Москвою шрать будешь"8 (Archiwum Książąt Sanguszków w Sławucie, 1554-1572, 1910, p. 187).

The origin of the theme of Prince Roman who ploughed the fields using Lithuanians instead of oxen and horses is not particularly clear. The earliest source, other than Kmita's letter, where the context can be found is Maciej Stryjkowski's Chronicle of Poland, Lithuania, Samogitia and all the Ruthenia (Stryjkowski, 1846, pp. 202, 211), published originally in 1582. The chronicler mentioned the theme of ploughing with Lithuanians and Yotvingians (Litwa $z$ Jaczwingami) in two contexts: when describing the reign of Roman Rostislavich in Kiev (before 1077) (Stryjkowski, 1846, p. 202) and later - Roman Mstislavich the Great (died 1205). Ivan Zhdanov (ZHdanov, 1895, p. 437) considered the second reference a mistake, while Aleksandr Rogov (Rogov, 1966, p. 99) later suggested that Stryjkowski's peculiar narrative style, which often repeats phrases ("Romanie, Romanie! Lichym się karmisz, Litwuju oreż!") $)^{9}$ and gives a double account of one and the same event, proved that the source he utilized in this case was not a Ruthenian chronicle but some oral tradition where Prince Roman was mentioned without specific identification. Kmita's reference likewise does not inform us which Roman is being mentioned, and this fact also points to the existence of some legendary plot.

The source of Stryjkowski's narrative, defined by Rogov as a Lithuanian oral story, should in our opinion be considered a Ruthenian one - the Chronicle only help us to clarify the general outline of the story. In the Chronicle, Ruthenians (Rus') are contrasted with Lithuanians (Litva), described as "woodsmen," pagans who do not know the Ruthenian language. This chapter allows us to pinpoint the criteria of differentiation

\footnotetext{
8 "Be, my lord, like that Roman who ploughed with the Lithuanians [i.e., had Lithuania as his plough - I.K.], then by the Grace of God you shall plough with the Muscovites ['Moscow']."

9 "Roman, Roman! You feed on calamities, you plough with Lithuania."
} 
between Lithuania and Rus' propagated by this tradition - namely, territory, language and faith. Kmita regards the story of Prince Roman as something to be proud of, and assumes that this context would be wellknown to Roman Sanguszko as well. This juxtaposition of Rus' led by prince Roman to Lithuania suggests the idea that there was a memory of Rus' as a sovereign state within the Ruthenian population of the Grand Duchy of Lithuania.

In letter to Ostafi Wołłowicz of 5 August 1574, when thinking over the perspectives of the new election after Henri de Valois left the Polish-Lithuanian state, Kmita shares concerns of "our people" - Lithuanian Senators:

Не дай бог ляху быть. Вырежет Литву а Русь поготову!» Давно резать почали литвина. И тот, де, с прыроженя натуры на себе сам необачное... просто як овца: где их больш берет волк, там оне дальш за ним идут. Большы будет жычлившый нороду польскому, нижели своему ${ }^{10}$ (Korshunaŭ, 1975, p. 87).

In this context, Lithuania and Rus' are two components of "our" nation opposed to Poles, who are dangerous and not favourable to the citizens of the Grand Duchy of Lithuania.

The word "Rus" is found in Kmita's letters also in a geographical sense. He defines a part of Muscovite-Lithuanian Borderland from Smolensk to Orsha as "сии руские украины"11 (Korshunaŭ, 1975, p. 57). This fact demonstrates that Rus' was still widely understood in geographical terms at the time immediately following the Union of Lublin. The way Filon Kmita perceives Rus' as a territory seems to be long established in his "inner-circle." Both Roman Sanguszko and Hrehory Chodkiewicz used the term Rus' as a geographical notion, defining it specifically as "панство Его Милости господарское украиное," "12 “украина руская от Москвы” (Archiwum Książąt Sanguszków w Sławucie, 1554-1572, 1910, p. 116). We also encounter more substantial exemplifications of the semantic content of Rus' - Roman Sanguszko wrote to Sigismundus Augustus: "[...] dla czego Wasza królewska Miłość, moy miłościwy pan, tę miłą ojczyznę swoję, roskoszny, a prawie święty kraj, pańśtwo swoje, ziemię Ruską, w opanowanie

\footnotetext{
10 ' 'God forbid that a Pole is [the King]. He will massacre Lithuania and Rus' - all the more.' The Lithuanians have long been massacred. But they are so careless about themselves, just like sheep - the more a wolf snatches them, the more they follow the wolf. [A Lithuanian] would be more kind to the Polish nation, than to his own."

11 "These Ruthenian borderlands."

12 "Borderland state of His Grace the Hospodar."

13 "Ruthenian borderland with Moscow."
} 
nieprzyjacielowi swojemu posiadać dopuszczać raczysz [...]"14 (Archiwum Książąt Sanguszków w Sławucie, 1554-1572, 1910, p. 262). The Field Hetman went on to state that failures of the Lithuanian army were God's punishment for breaking with the traditional political order centred around the person of the monarch (Archiwum Książąt Sanguszków w Stawucie, 1554-1572, 1910, p. 263).

Ostafi Wołłowicz is also treated in the correspondence as someone belonging to "our" Ruthenian tradition. In his letters to Wołłowicz, Kmita assumes not only that his addressee cares about the fate of Rus' after the new election but also that he knows the epic plots about Ilia Moravlenin and Solovej Budimirovich. The fact that the story must have been familiar to both the correspondents, Wołłowicz as well as Kmita, has long served scholars as a source for considerations about the geographical scope of common cultural elements (Veselovskiŭ, 1881, p. 61).

The last issue we are going to touch upon is the problem of using the term "nation" (naród) in the correspondence of Filon Kmita. As was already mentioned, writing to Ostafi Wołłowicz about the danger of electing of a Pole to the throne of the Polish-Lithuanian Commonwealth, Kmita voiced a regret that Lithuanians are more favourable to the Polish nation than to their own.

Elsewhere in his letters, after Roman Saguszko's victory in the Battle of Czaśniki (Chashniki), Filon wishes “абы в несмертельной славе Вашей Милости и народови всему великого кнАзства Литовского таковое щастье над неприАтелем господарским долгий час трвало"15 (Archiwum Książąt Sanguszków w Sławucie, 1554-1572, 1910, p. 187).

As is evident from these usages, Kmita applies the term "nation" to designate the community of citizens of the Grand Duchy of Lithuania. This understanding fully corresponds to the predominate discourse of that time - the idea of the political nation (Bardach, 1995, p. 26). The nation of the Grand Duchy was composed of two elements - Lithuania and Rus' - and was Kmita's group of self-identification.

The present paper offers a preliminary attempt at reconstructing the environment of Filon Kmita Czarnobylski. Especially the problem of relations of clientelism requires further development. But already at this stage we can notice that even the closest circle of the Palatine of Smolensk was varied in terms of religion and wide in terms of its geographical

\footnotetext{
14 "Why do you, Your Royal Grace, my dear lord, let the enemy seize control over your lovely homeland, delightful and truly holy land, your state, the land of Rus."

15 " $[. .$.$] to Your Grace and all the nation of the Grand Duchy of Lithuania to have this fortune$ over the enemy of the Hospodar last for a long time in deathless glory."
} 
scope. Looking back to previous generations of his ancestors, his family connections stretch even farther, encompassing the Vyazma and Smolensk Lands under the reign of Alexander Jagiellon. Within the closest, "inner" group, official relations were supported by ties of marriage and friendship.

The perception of "Lithuania" on the part of Filon Kmita is twofold. On the one hand, Lithuania comes to mean the Great Duchy of Lithuania, and in this sense the Lithuanian nation is treated by Kmita as his own group. The main characteristic of the Lithuanian identity for Kmita is military service under the Grand Duke. This identity is supported within the circle of citizens of the Grand Duchy by collective memory and family tradition. That is why this "we-group" embraces a wider circle, including also the Radziwiłłs.

In the other sense, Lithuania is an ethnic group of "others." It is contrasted with Rus' - "us" - and the criteria of contrast are territory, faith and language. Appealing to the idea of Rus', Kmita fills this notion with geographical and social senses. The Orthodox religion was one of the features of Rus' propagated by the tradition. In practice, however, faith proved not to be the most important thing. The "closest circle" of Filon Kmita includes the Orthodox Hrehory Chodkiewicz, Roman Sanguszko, Bohdan Sapieha, Konstanty Ostrogski, Juryj Drucki-Horski, the Kroszyński family as well as the Catholics Lew Sapieha, Dymitr Chalecki, and the Protestant Ostafi Wołłowicz. Neither did religion determine one's inclusion into the circle of Ruthenians (Rus'), as is exemplified by Kmita’s letter to Wołłowicz in which he refers to their common tradition. On the other hand, Orthodox Muscovy is contrasted, by Kmita as well as by Roman Sanguszko, not only with the Grand Duchy of Lithuania but also with Rus'.

In sum, the Ruthenian identity of Filon Kmita can be characterized as based on the tradition, awareness of the common origin and memory of the once-independent state of Rus'.

\section{References}

Akty, otnosiashchiiesia $k$ istorii Zapadno ̌ Rossii, sobrannye $i$ izdannye arkheograficheskoiu komissieiu. (1848) (Vol. 3). S. Petersburg: Tipografïia Ė. Pratsa.

Archiwum Książąt Sanguszków w Sławucie, 1554-1572. (1910) (Vol. 7). Lwów: Drukarnia Instytutu Stauropigijskiego.

Arkheograficheskī sbornik dokumentov, otnosiashchikhsia $k$ istorīi Severo-Zapadno Rusi. (1867a) (Vol. 1). Vil'na: Pechatnia Gubernskago Pravlenīia.

Arkheograficheskī sbornik dokumentov, otnosiashchikhsia $k$ istorïi Severo-Zapadno Rusi. (1867b) (Vol. 4). Vil'na: Pechatnia Gubernskago Pravleniia.

Augustyniak, U. (2004). W stużbie hetmana i Rzeczypospolitej: Klientela wojskowa Krzysztofa Radziwiłła (1585-1640). Warszawa: „Semper”. 
Bardach, J. (1995). Wieloszczeblowa świadomość narodowa na ziemiach litewsko-ruskich Rzeczypospolitej w XVII-XX w. In Pamiętnik 15 Powszechnego Zjazdu Historyków Polskich (Vol. 1/1). Gdańsk: Wydawnictwo Adam Marszałek.

Batory, S. (1585, February 26). Stefan Batory do Filona Kmity, Warszawa, 26.02.1585. AGAD, AR Dz. II 3409. Warsaw.

Batory, S. (1577, November 25). Stefan Batory do Filona Kmity, Malbork, 25.11.1577. AGAD, Archiwum Potockich z Radzynia, 349, mkv 92419. Warsaw.

Boniecki, A. (1907). Herbarz Polski (Vol. 10). Warszawa: Skład główny Gebethner i Wolff.

Czwołek, A. (2012). Piórem i buława: Działalność polityczna Lwa Sapiehy, kanclerza litewskiego, wojewody wileńskiego. Toruń: Wydawnictwo Naukowe Uniwersytetu Mikołaja Kopernika.

Eberle, J. (1967-1968). Filon Kmita Czarnobylski. In Polski słownik biograficzny (Vol. 13, pp. 88-89). Wrocław, Warszawa, Kraków: Zakład Narodowy im. Ossolińskich.

Floria, B. (1975). Wschodnia polityka magnatów litewskich w okresie pierwszego bezkrólewia. Odrodzenie i Reformacja $w$ Polsce, 20, 45-67.

Gawlas, S. (1983). Świadomość narodowa Jana Długosza. Studia Źródłoznawcze, 27, $3-66$.

Halecki, O. (1937). Dymitr Chalecki. In Polski słownik biograficzny (Vol. 3, pp. 247-248). Kraków: Polska Akademia Umiejętności.

Hrushevs'kyı̆, M. (1995). Istoriia ukraïns'koï literatury (Vol. 5/1). Kyïv: Lybid'.

IAkovenko, N. (2008). Ukraïns'ka shliakhta z kintsia XIV do seredyny XVII stolittia: Volyn' i TSentralna Ukrä̈na. Kyïv: Krytyka.

IAkovenko, N. (2012). Zhittieprostir versus identychnist' rus'koho shliakhtycha XVII stolittia (na prykladi Iana/Ĭoakyma IErlicha). In N. IAkovenko, Dzerkala identychnosti: Doslidzhennia $z$ istorii uiavlen' ta ideı̆ v Ukrä̈ni XVI - pochatku XVIII st. (pp. 63-118). Kyïv: Laurus Press.

IAnushkevich, A. (2007). Vialikae Kniastva Litoŭskae i Infliantskaia vă̌na 1558-1570 gg. Minsk: Medisont.

Karskil̆, E. (1916). Belorussy (Vol. 3/2). Moskva: Rossiī̌skaia Gosudarstvennaia Akademicheskaia Tipografiiia.

Koczerska, M. (1970). Mentalność Jana Długosza w świetle jego twórczości. Studia Źródłoznawcze, 15, 109-140.

Korshunaŭ, A. (1975). Pomniki starazhytnă̌ belaruskă̌ pis’mennastsi. Minsk: Navuka i tèkhnika.

Kotarski, H. (1972). Wojsko polsko-litewskie podczas wojny inflanckiej 1576-1582: Sprawy organizacyjne (cz. 5). Studia i Materiały do Historii Wojskowości, 18, 43-98.

Krykun, M. (Ed.). (2008). Dokumenty Bratslavskoho voievodstva 1566-1606 rokiv. Kyïv: Nauk. t-vo im. Shevchenka.

Lesmaitis, G. (2013). Wojsko zaciężne w Wielkim Księstwie Litewskim w końcu XV-drugiej połowie XVI wieku. (B. Piasecka, Trans.). Warszawa: Wydawnictwo Neriton. 
Liedke, M. (2004a). Od prawosławia do katolicyzmu: Ruscy możni i szlachta Wielkiego Księstwa Litewskiego wobec wyznań reformacyjnych. Białystok: Wydawnictwo Uniwersytetu w Białymstoku.

Liedke, M. (2004b). Państwowa, religijna, czy narodowa tożsamość? Ruscy możni i szlachta w Wielkim Księstwie Litewskim i w Rzeczypospolitej. In Istoriniai tekstai ir vietos kultūra: Moksliniu straipsniu rinkinys, skirtas Lietuvos vardo paminejimo tükstantmečiui [Historical scripts and local culture: collection of scientific articles dedicated to the millenium of mentioning the name of Lithuania] (pp. 192-200). Riga: Lucilijus.

Lietuvos Metrika. (2001). T. Knyga Nr. 12.Užrašymų knyga 12. Vilnius.

Litwin, H. (2009). Równi do równych: Kijowska reprezentacja sejmowa 1569-1648. Warszawa: Wydawnictwo DiG.

Litwin, H. (2011). Suviazi elity VKL z Kyevshchynaï u 1569-1648. Belaruski histarychny ahliad, 18, 3-21.

Lulewicz, H. (1977). Skład wyznaniowy senatorów świeckich Wielkiego Księstwa Litewskiego za panowania Wazów. Przegląd Historyczny, 68, 425-445.

Lulewicz, H. (1994). Lew Sapieha. In Polski słownik biograficzny (Vol. 35). Kraków: Polska Akademia Umiejętności.

Lulewicz, H., \& Rachuba, A. (1994). Urzędnicy centralni i dygnitarze Wielkiego Księstwa Litewskiego XIV-XVIII wieku: Spisy. Kórnik: Biblioteka Kórnicka.

Malinowski, M., \& Przeździecki, A. (Eds.). (1844). Źródła do dziejów polskich (Vol. 2). Wilno: J. Zawadzki.

Malinowski, M. (1844). Wiadomość o Filonie Kmicie Czarnobylskim. In M. Malinowski \& A. Przeździecki (Eds.), Źródła do dziejów polskich (pp. 306-343). Wilno: J. Zawadzki.

Miller, V. (2015). Ocherki russkoŭ narodnoŭ slovesnosti. Moskva: Institut russkoŭ tsivilizatsii.

Nowicka, E. (1990). Swojskość i obcość jako kategorie socjologicznej analizy. In E. Nowicka (Ed.), Swoi i obcy (pp. 5-53). Warszawa: Uniwersytet Warszawski, Instytut Socjologii.

Pietkiewicz, K. (1995). Wielkie Księstwo Litewskie pod rzadami Aleksandra Jagiellończyka: Studia nad dziejami państwa i społeczeństwa na przełomie XV i XVI wieku. Poznań: Wydawnictwo Naukowe Uniwersytetu im. Adama Mickiewicza.

Prochaska, A. (Ed.). (1892). Archiwum domu Sapiehów wydane staraniem rodziny (Vol. 1, Listy z lat 1575-1606). Lwów: Nakład rodziny.

Rogov, A. (1966). Russko-pol'skie kul'turnye sviazi w epokhu Vozrozhdeniia. Moskva: Nauka.

Rusetskiŭ, A., \& Rusetskiŭ, I. (2008). Khudozhestvennaia kul'tura Vitebshchiny: Poozer'e, Podvin'e, Verkhnee Podneprov'e. Vitebsk: VHU im. P. M. Masherova.

Saverchanka, I. (2006). Ėpistaliarnaia spadchyna Filona Kmity-Charnabyl'skaha. Belaruski histarychny chasopis, 5, 29-33.

Slizh, N. (2009). Sprava adnaho naezdu, abo pra reputatsyiu L'va Sapehi. Belaruski histarychny ahliad, 16, 113-119. 
Sobolevskiü, A. (1889). K” istorīi russkikh" bylin”. Zhurnal" Ministerstva narodnago prosveshchènīia, (264), 15-19.

Stryjkowski, M. (1846). Kronika polska, litewska, żmódzka i wszystkiéj Rusi Macieja Stryjkowskiego (Vol. 1). Warszawa: Gustaw Leon Glücksberg.

Temushev, V. (2007). K voprosu o moskovsko-litovskoı granitse XV v. (Vladeniia kniazeĭ Kroszynskikh). Ruthenica, 299-307.

Veselovskiŭ, A. (1881). IUzhno-russkiia byliny. S.-Peterburg: Tipografiia Imperatorskoŭ akademīi nauk.

Wolff, J. (1895). Kniaziowie litewsko-ruscy od końca czternastego wieku. Warszawa: Gebethner i Wolff.

ZHdanov, I. (1895). Russkiŭ bylevoù èpos: Izsledovaniia i materialy. S.-Peterburg: Izdanie L. F. Panteleeva.

Źródła dziejowe: Vol. 21, Polska XVI wieku pod względem geograficzno-statystycznym. Vol. 10, Ziemie ruskie. Ukraina (Kijów-Bracław). Dz II. Opisane przez Aleksandra Jabłonowskiego.(1894). Warszawa: Gebethner i Wolff.

\section{„W kręgu swoich”: \\ O świadomości ruskiej szlachty \\ Wielkiego Księstwa Litewskiego w dobie Unii Lubelskiej (na przykładzie Filona Kmity Czarnobylskiego)}

Głównym zadaniem mojego artykułu jest rekonstrukcja postrzegania „swojskości” przez ruskiego szlachcica z drugiej połowy XVI wieku oraz analiza jego wielopoziomowej świadomości, która umożliwi usytuowanie tego pojęcia w systemie odniesień poszczególnych grup i zbiorowości społecznych.

Szczególnie istotne wydaje się zbadanie horyzontów i wyobrażeń przeciętnego przedstawiciela ruskiego narodu politycznego Wielkiego Księstwa Litewskiego w XVI wieku, dotychczas uczeni skupiali się bowiem najczęściej na wyobrażeniach elit (zwłaszcza ich pojedynczych przedstawicieli) lub intelektualistów, a związki klientalne poszczególnych rodzin ruskich, niezwykle istotne dla skonstruowania całościowego obrazu, praktycznie nie były przez nich jeszcze badane.

Jedna z najważniejszych tez mojego artykułu zakłada, że świadomość przynależności do takiego „kręgu swoich” była jednym z nieodłącznych elementów ówczesnej ruskiej tożsamości. Jednocześnie zarówno postrzeganie „swoich”, jak i świadomość narodowa ruskiej szlachty charakteryzowały się wielopoziomową strukturą. 
Aby uzyskać rzucić światło na tak postawione kwestie, analizie poddam korespondencję osobistą Filona Kmity, jego powiązania społeczno-rodzinne, związki małżeńskie, zależności klientalne, praktyki społeczne, otoczenie wojskowe i służbowe. Takiego rodzaju podejście może pomóc nie tylko w przedstawieniu konkretnej jednostki (wprawdzie wybitnej, ale pozostającej poza środowiskiem elity Wielkiego Księstwa Litewskiego), lecz również w prezentacji trzeciego największego narodu Rzeczypospolitej w XVI wie$\mathrm{ku} \mathrm{z}$ punktu widzenia jednego $\mathrm{z}$ jego przedstawicieli.

\section{Note}

Irina Koluzaeva [Ирина Колузаева], Faculty of “Artes Liberales," University of Warsaw, Warsaw acoro@rambler.ru

The article was written during the author's PhD Programme at the Faculty of "Artes Liberales," University of Warsaw, within the Aurora Erasmus Mundus Action 2, Strand $1(2013$ - 2016).

No competing interests have been declared. 